\title{
Sjögren's and plasma cell variant Castleman disease: a case report
}

\author{
Yvonne A. Dei-Adomakoh ${ }^{1}$, Leslie Quarcoopome ${ }^{2}$, Afua D. Abrahams ${ }^{3}$, Catherine I. Segbefia ${ }^{4}$ and \\ Dzifa I. Dey ${ }^{5}$
}

Ghana Med J 2018; 52(3): 61-65

DOI: http://dx.doi.org/10.4314/gmj.v52i1.9

${ }^{1}$ Department of Haematology, University of Ghana School of Biomedical and Allied Health Sciences, PO Box GP 4236, Accra, Ghana, ${ }^{2}$ Korle Bu Teaching Hospital, Accra, Ghana, ${ }^{3}$ Department of Pathology, University of Ghana School of Biomedical and Allied Health Sciences, PO Box GP 4236, Accra, Ghana, ${ }^{4}$ Department of Child Health, University of Ghana School of Medicine \& Dentistry, Accra, Ghana, ${ }^{5}$ Department of Medicine \& Therapeutics, University of Ghana School of Medicine and Dentistry, Accra, Ghana

\author{
Corresponding author: Dr Yvonne Akotoa Dei-Adomakoh \\ E-mail: deiadom@yahoo.com
}

Conflict of interest: None declared

\section{SUMMARY}

Castleman disease is a rare cause of lymphoid hyperplasia and may result in localized symptoms or an aggressive, multisystem disorder. It can mimic other diseases like lymphoma or tuberculosis. It classically presents as a mediastinal mass that involves the lymphatic tissue primarily but can also affect extra lymphatic sites including the lungs, larynx, parotid glands, pancreas, meninges, and muscles. In HIV and HHV8-negative patients with idiopathic multicentric Castleman disease, pathogenesis may involve autoimmune mechanisms. We highlight and report a case of a 34-year-old Ghanaian female who was successfully diagnosed and managed for Sjögren's as well as plasma cell variant Castleman disease with combination chemotherapy and rituximab followed by eighteen months maintenance therapy with pulse chlorambucil and prednisolone and three monthly rituximab.

Keywords: lymphadenopathy, chemotherapy, Rituximab, Plasma Cell Variant Castleman Disease, Sjögren's syndrome

\section{INTRODUCTION}

Castleman disease (CD) is a polyclonal lymphoproliferative disorder also known as giant nodular hyperplasia or angiofollicular lymph node hyperplasia, angiomatous lymphoid hamartoma, lymph node hamartoma, and benign giant lymphoma. ${ }^{1}$ The first case report of $C D$ was published in 1956 by Castleman et al and he later described 13 patients with unicentric hyaline vascular CD of the chest. ${ }^{2}$

CD is a rare disease and classically presents as a mediastinal mass that primarily involves the lymphatic tissue $^{3-5}$ but can affect extra lymphatic sites including the lungs, larynx, parotid glands, pancreas, meninges, and muscles. ${ }^{3-5}$

Clinical presentation ranges from unicentric or localized lymph node involvement to a severe, multicentric, systemic disorder which is associated with constitutional signs and symptoms such as fever, night sweats, easy fatigability and anaemia. ${ }^{6,7}$
The underlying cause of CD remains unknown although both immunodeficiency and autoimmunity have been suggested. CD has been described in association with autoimmune and connective tissue diseases such as rheumatoid arthritis, myasthenia gravis, Evans' syndrome, vitiligo, coeliac disease, Graves' disease, ulcerative colitis and immune thrombocytopenia ${ }^{8,6-11}$ and this may suggest a possible autoimmune pathology. ${ }^{12}$ However, it is not clear if autoimmunity is the underlying cause or result of $\mathrm{CD}$. It has also been described with POEMS syndrome (polyneuropathy, organomegaly, endocrinopathy, $\mathrm{M}$ component, skin changes $)^{13,14}$ Localized disease can be cured by surgical resection of the affected lymph node while aggressive systemic therapy is required in Multicentric Castleman disease (MCD). ${ }^{15,16}$

We present an obese 34 year old Ghanaian female with Sjögren's and plasma cell variant CD who presented with the classical signs of Sjögren's and was found to have massive lymphadenopathy as well. 
She also had marked constitutional symptoms and was treated with six cycles of multiagent chemotherapy and rituximab (anti-CD-20 monoclonal antibody) followed by eighteen months maintenance therapy with monthly pulses of chlorambucil and prednisolone and threemonthly rituximab.

\section{CASE REPORT}

A 34-year-old female was referred for a haematology consult on account of thrombocytosis following a diagnosis of Sjögren's disease at a private clinic. Patient had been unwell the preceding six months with a cold, dry mouth, excessive sweating but no history of weight loss. On examination, she was very severely obese with a BMI of 64.7 (weight $187 \mathrm{~kg}$, height $170 \mathrm{~cm}$ ) not pale, afebrile, with swollen eyelids and enlarged submandibular lymph nodes. Both lower limbs were swollen and tender with differential warmth. The liver and spleen were not enlarged.

Laboratory tests done showed anaemia, elevated serum lactate dehydrogenase but liver function, renal function and uric acid levels were normal. Serum inflammatory markers, erythrocyte sedimentation rate and C-reactive protein, were elevated $-98 \mathrm{~mm} / \mathrm{hr}$ and $20.6 \mathrm{mg} / \mathrm{dL}$, respectively. HIV, Hepatitis B and C viral screening were negative. Serum HHV8 immunofluorescence assay was done and found to be negative. (Table 1) An abdominopelvic ultrasound scan done to determine the presence of intra-abdominal lymphadenopathy was normal.

Table 1 Summary of Full Blood Count and other Laboratory results

\begin{tabular}{|c|c|c|c|}
\hline Index & $\begin{array}{l}\text { Before } \\
\text { chemothera- } \\
\text { py }\end{array}$ & $\begin{array}{l}\text { After chem- } \\
\text { otherapy }\end{array}$ & $\begin{array}{l}\text { Reference } \\
\text { range }\end{array}$ \\
\hline $\mathrm{Hb}$ (gldl) & 8.9 & 12.0 & $(11.0-16.0)$ \\
\hline $\mathrm{MCV}(\mathrm{fl})$ & 71.3 & 85 & $(84-96)$ \\
\hline $\mathrm{MCH}(\mathrm{pg})$ & 21.7 & 27.2 & $(26-32)$ \\
\hline $\mathrm{WBC}\left(\mathrm{x} 10^{9} / \mathrm{l}\right)$ & 6.6 & 3.8 & $(2.5-8.5)$ \\
\hline Platelets (x 109/1) & 381 & 211 & $(140-400)$ \\
\hline HIV $1 \& 11$ & Negative & & \\
\hline $\begin{array}{l}\text { C-reactive protein } \\
(\mathrm{mg} / \mathrm{l})\end{array}$ & 20.6 & 6.0 & $0.00-8.0$ \\
\hline ESR mm/hr & $98 \mathrm{~mm} / \mathrm{hr}$ & 15 & $4-7$ \\
\hline $\mathrm{LDH}(\mathrm{U} / \mathrm{L})$ & 502 & 360 & $100-480$ \\
\hline Hepatitis B \& C & Negative & & \\
\hline Uric acid (Umol/L) & 289 & 235 & $149-446$ \\
\hline
\end{tabular}

An excisional biopsy of a submandibular lymph node was taken. Histology showed lymphoid follicles with reactive germinal centers surrounded by concentric layers of small mature appearing lymphocytes.
The interfollicular zones were expanded by a polymorphous mononuclear cell population with sheets of plasma cells present, which were mature to immature in morphologic appearance. A diagnosis of plasma cell variant of $C D$ was made. Using the recently proposed consensus criteria, ${ }^{17}$ our patient had two major (characteristic lymph node histopathology and multicentric lymphadenopathy), and three of 11 minor Criteria (elevated C-reactive protein, anaemia, and constitutional symptoms). There was no histological evidence of malignant lymphoma. Immunohistochemistry is not routinely done in Ghana and was not requested.

Patient was treated with 8 cycles of RCHOP (rituximab, cyclophosphamide, vincristine, doxorubicin and prednisolone), given at 3 weekly intervals. With the commencement of chemotherapy came rapid improvement in the patient's clinical symptoms as well as resolution of peripheral lymphadenopathy. Maintenance therapy consisting of monthly pulses of chlorambucil and prednisolone as well as three monthly courses of rituximab was given. Patient had maintenance therapy for eighteen months and was subsequently lost to follow-up. She presented again after five years with bilateral lacrimal, submandibular, cervical lymphadenopathy and constitutional symptoms. A repeat lymph node biopsy revealed a relapse of $\mathrm{CD}$. She was re-treated with RCHOP and went into a second clinical remission after six cycles of therapy with complete resolution of lymphadenopathy and constitutional symptoms. She is currently doing well on monthly pulses of chlorambucil.

\section{DISCUSSION}

This patient presented twice with some classical features of $\mathrm{CD}$ such as the non-specific constitutional symptoms and lymphadenopathy as well as features of Sjögren's syndrome. The manifestations of CD are nonspecific and require histological diagnosis. Sjögren's syndrome is a systemic autoimmune disease that mainly affects the exocrine glands with lymphocytic infiltration of the glands particularly the salivary and lacrimal glands leading to the development of xerostomia (dry mouth) and keratoconjunctivitis sicca (dry eyes) with eventual damage or destruction of the glands ${ }^{18}$ Sjögren's syndrome primarily affects predominantly Caucasian perimenopausal women, with an incidence of 4-5 cases per $100000 .{ }^{17}$ The syndrome can occur by itself (primary) or as secondary Sjögren's syndrome when it is associated with another connective tissue disease. In Sjögren's syndrome, a number of findings from literature have implicated the presence of a B-cell hyperactivity that may evolve to a lymphoproliferative disorder. ${ }^{18,19}$ 


\section{Case Report}

Our patient had a previous underlying autoimmune disorder in the form of Sjögren's and this autoimmune response may be the trigger of Castleman disease. ${ }^{19}$ The first reported case of MCD diagnosed in Ghana and successfully treated also had plasma cell variant and presented with two major and four minor criteria (constitutional symptoms, anaemia, thrombocytopenia and elevated ESR). ${ }^{20}$

The occurrence of B-cell non-Hodgkin lymphoma (NHL) represents the major complication in the evolution of Sjögren's syndrome. ${ }^{7,21}$ The risk of developing NHL, which is equivalent for both primary and secondary syndromes, is estimated to be over forty times greater than that observed in a comparable normal population. ${ }^{21} \mathrm{NHL}$ in patients with Sjögren's syndrome occur preferentially in salivary glands and in other mucosaassociated lymphoid tissues (MALT) but also in lymph nodes and bone marrow. Persistent enlargement of parotid glands, adenopathy, monoclonal gammopathy, and cross-reactive idiotypes are all signs suggesting possible progression to lymphoma. ${ }^{22}$ The progression from benign lymphocytic infiltration typical of Sjögren's syndrome to malignant NHL is undoubtedly a multistep process, but the causal molecular events are unknown. In the case presented, a biopsy done at time of relapse still showed $\mathrm{CD}$.

Some studies have implicated viruses like hepatitis B, Epstein Barr virus, and $\mathrm{T}$ lymphocytic viruses in the pathogenesis of Sjögren's syndrome and development of a cancer. ${ }^{23}$ Our patient was screened for hepatitis B, which was found to be negative. HHV8 is central to the pathogenesis of HIV-positive CD and occurs in 50\% of those patients. ${ }^{24}$ Our patient was HIV and HHV8 negative and thus most likely had idiopathic $\mathrm{CD}$ which is usually associated with an autoimmune disease.

Primary Sjögren's has also been described coexisting with $\mathrm{CD}$ in a few case reports and the Hyaline-vascular type of CD may be a lymphoproliferative disorder associated with Sjögren's syndrome. ${ }^{25,26}$ This patient however had Plasma cell type CD.

Unicentric Castleman disease (UCD), the less aggressive form of the disorder, presents as a solitary lesion. It is usually seen in young and middle aged patients without any sex predilection. The HV type is unicentric in $90 \%$ of the cases.

Histopathological findings in CD suggest an exaggerated response to antigenic stimuli seen in diseases associated with immune activation, such as rheumatoid arthritis. Chronic inflammation resulting from exposure to an unknown antigen has been supported by the presence of excessive serum levels of interleukin6 (IL6), a cytokine with widespread effects on the immune system and haematopoiesis. Some believe it may play a central role in the pathophysiology of $\mathrm{CD}$. The clinical features have been linked to IL6 serum levels, and surgical removal of the involved lymph nodes or use of anti-IL6 antibodies can slow down the symptoms. ${ }^{26,27} \mathrm{C}$-reactive protein which is a marker for IL6 was found to be very high in this patient prior to therapy. This normalized after chemotherapy.

\section{Treatment}

No curative agents for Sjögren's syndrome exist. The treatment of the disorder is essentially symptomatic. Recent studies ${ }^{26,28}$ have analyzed new therapeutic approaches, focusing mainly on the use of biological agents. B-cell targeted therapies seem to be the most promising agents in primary Sjögren's syndrome, especially rituximab (anti-CD 20 monoclonal antibody), which has been used in reported cases. CD20 is considered a specific marker for B cells, highly expressed on the surface of pre-B lymphocytes and both residing and activated mature B cells, but not expressed in other cells. ${ }^{26}$ Malignant lymphoma in Sjögren's syndrome are typically a monoclonal B-cell neoplasm which may explain why rituximab should be considered a choice in their treatment. ${ }^{28}$ In some studies however, rituximab did not provide lasting benefit for patients with primary Sjögren's syndrome as it did not alleviate symptoms or disease activity at later end points. ${ }^{29}$

Successful treatment of MCD has been reported using rituximab $^{30-32}$ in both HIV positive and negative patients, even when used as salvage therapy. It was first used for the treatment of HIV positive patients with MCD after chemotherapy-induced remission. Most MCD cases treated to date with rituximab have been HIV and HHV-8 positive patients. ${ }^{33-36}$ Rituximab was chosen in our patient as the first-line treatment since she also had a history of Sjögren's syndrome.

The limitations of this report were the inability to get micrographs of the histology that was done on the lymph node biopsy and also immunophenotyping was not done to differentiate Castleman disease from a lymphoma.

\section{CONCLUSION}

Clinicians should be aware that Sjögren's can co-exisit with Castleman disease. Therefore, investigation of patients with suspected autoimmune disease and lymphadenopathy should include lymph node biopsy for histology and immunohistochemistry where possible. Monoclonal antibodies such as rituximab can also be used in the treatment of both Sjögren's disease and CD in combination with other chemotherapeutic agents. 


\section{ACKNOWLEDGEMENT}

We the authors thank the young lady in this report for allowing us share her details.

\section{REFERENCES}

1. Bonekamp D, Horton KM, Hruban RH, Fishman EK. Castleman disease: the great mimic. Radiographics. 2011;31(6):1793-807.

2. Castleman B, Iverson L, Menendez VP. Localized mediastinal lymph- node hyperplasia resembling thymoma. Cancer. 1956;9(4):822-30.

3. Johkoh T, Müller NL, Ichikado K, Nishimoto N, Yoshizaki K, Honda O, et al. Intrathoracic multicentric Castleman disease: CT findings in 12 patients. Radiology. 1998;209(2):477-81. PubMed PMID: 9807577.

4. Keller AR, Hochholzer L, Castleman B. Hyalinevascular and plasma-cell types of giant lymph node hyperplasia of the mediastinum and other locations. Cancer. 1972 Mar;29(3):670-83. PubMed PMID: 4551306. Epub 1972/03/01. eng.

5. McAdams HP, Rosado-de-Christenson M, Fishback NF, Templeton PA. Castleman disease of the thorax: radiologic features with clinical and histopathologic correlation. Radiology. 1998;209(1):221-8. PubMed PMID: 9769835.

6. Kassan SS, Thomas TL, Moutsopoulos HM, Hoover R, Kimberly RP, Budman DR, et al. Increased risk of lymphoma in sicca syndrome. Annals of internal medicine. 1978 Dec;89(6):888-92. PubMed PMID: 102228. Epub 1978/12/01. eng.

7. Lazarus MN, Robinson D, Mak V, Moller H, Isenberg DA. Incidence of cancer in a cohort of patients with primary Sjogren's syndrome. Rheumatology (Oxford, England). 2006 Aug;45(8):1012-5. PubMed PMID: 16490754. Epub 2006/02/24. eng.

8. Higashi K, Matsuki Y, Hidaka T, Aida S, Suzuki K, Nakamura H. Primary Sjogren's syndrome associated with hyaline-vascular type of Castleman's disease and autoimmune idiopathic thrombocytopenia. Scandinavian journal of rheumatology. 1997;26(6):482-4. PubMed PMID: 9433413. Epub 1997/01/01. eng.

9. Lee SK, Kim DH, Son BS. Castleman's Disease with Myasthenia Gravis. The Korean journal of thoracic and cardiovascular surgery. 2012 Jun;45(3):199-201. PubMed PMID: 22708092. Pubmed Central PMCID: PMC3373980. Epub 2012/06/19. eng.

10. Soumerai JD, Sohani AR, Abramson JS. Diagnosis and management of castleman disease. Cancer Control. 2014;21(4):266-78.

11. Muela Molinero A, Ballesteros del Rio B, Sandoval Guerra V, Llor Baños J. Evans syndrome as presentation of multicenter Castleman disease. Revista
Clinica Espanola. 2003;203(12):616-617. [PubMed]

12. Marsh JH, Colbourn DS, Donovan V, Staszewski H. Systemic Castleman's disease in association with Evan's syndrome and vitiligo. Medical and pediatric oncology. 1990;18(2):169-72. PubMed PMID: 2304424. Epub 1990/01/01. eng.

13. Thoufeeq MH, Perry MJ. Castleman's disease in a patient with celiac disease. Indian journal of gastroenterology : official journal of the Indian Society of Gastroenterology. 2007 Jul-Aug;26(4):187. PubMed PMID: 17986750. Epub 2007/11/08. eng.

14. Loy M, Perra E, Siotto P, Argiolas A, Melis A, Cianchetti ME, et al. Gray-scale and color Doppler sonographic findings in a case of mesenteric Castleman's disease incidentally detected in a patient with Graves' disease. Journal of clinical ultrasound : JCU. 2005 Sep;33(7):356-9. PubMed PMID: 16196012. Epub 2005/10/01. eng.

15. Browne D, Barton EN, Barrow KO, Williams NP, Hanchard B. Multicentric angiofollicular lymph node hyperplasia in ulcerative colitis. A case report. The West Indian medical journal. 1996 Mar;45(1):34-6. PubMed PMID: 8693737. Epub 1996/03/01. eng.

16. De Marchi G, De Vita S, Fabris M, Scott CA, Ferraccioli G. Systemic connective tissue disease complicated by Castleman's disease: report of a case and review of the literature. Haematologica. 2004 Apr;89(4):ECR03. PubMed PMID: 15075095. Epub 2004/04/13. eng.

17. Fajgenbaum DC, Uldrick TS, Bagg A, Frank D, Wu D, Srkalovic G, Simpson D, Liu AY, Menke D, Chandrakasan S, Lechowicz MJ, Wong RS, Pierson S, Paessler M, Rossi JF, Ide M, Ruth J, Croglio M, Suarez A, Krymskaya V, Chadburn A, Colleoni G, Nasta S, Jayanthan R, Nabel CS, Casper C, Dispenzieri A, Fosså A, Kelleher D, Kurzrock R, Voorhees P, Dogan A, Yoshizaki K, van Rhee F, Oksenhendler E, Jaffe ES, Elenitoba-Johnson KS, Lim MS. International, evidence-based consensus diagnostic criteria for HHV-8-negative/idiopathic multicentric Castleman disease. Blood. 2017 Mar 23;129(12):1646-1657. doi: 10.1182/blood-201610-746933. Epub 2017 Jan 13.

18. Fazakas A, Csire M, Berencsi G, Szepesi A, Matolcsy A, Jakab L, et al. Multicentric plasmocytic Castleman's disease with polyneuropathy, organomegaly, endocrinopathy, $M$ protein, skin changes syndrome and coexistent human herpes virus-6 infection--a possible relationship. Leukemia \& lymphoma. 2009 Oct;50(10):1661-5. PubMed PMID: 19863339. Epub 2009/10/30. eng.

19. Misri R, Kharkar V, Dandale A, Patel V, Mahajan S, Khopkar U. Multiple capillary hemangiomas: a 
distinctive lesion of multicentric Castleman's disease and POEMS syndrome. Indian journal of dermatology, venereology and leprology. 2008 JulAug;74(4):364-6. PubMed PMID: 18797059. Epub 2008/09/18. eng.

20. Dei-Adomakoh YA, Segbefia CI, Ekem I, Taylor A. Multicentric Castleman's disease in a Ghanaian adult. Ghana Med J. 2013 47(2): 92-95 PMCID: PMC3743110

21. Tavoni A, Vitali C, Baglioni P, Gerli R, Marchetti G, Di Munno O, et al. Multicentric Castleman's disease in a patient with primary Sjogren's syndrome. Rheumatology international. 1993;12(6):251-3. PubMed PMID: 8484099. Epub 1993/01/01. eng.

22. Lazarus MN, Robinson D, Mak V, Moller H, Isenberg DA. Incidence of cancer in a cohort of patients with primary Sjogren's syndrome. Rheumatology (Oxford, England). 2006 Aug;45(8):1012-5. PubMed PMID: 16490754. Epub 2006/02/24. eng.

23. Fox RI, Howell FV, Bone RC, Michelson P. Primary Sjogren syndrome: clinical and immunopathologic features. Seminars in arthritis and rheumatism. 1984 Nov;14(2):77-105. PubMed PMID: 6399627. Epub 1984/11/01. eng.

24. Kassan SS, Thomas TL, Moutsopoulos HM, Hoover R, Kimberly RP, Budman DR, et al. Increased risk of lymphoma in sicca syndrome. Annals of internal medicine. 1978 Dec;89(6):888-92. PubMed PMID: 102228. Epub 1978/12/01. eng.

25. Anaya JM, McGuff HS, Banks PM, Talal N. Clinicopathological factors relating malignant lymphoma with Sjogren's syndrome. Seminars in arthritis and rheumatism. 1996 Apr;25(5):337-46. PubMed PMID: 8778989. Epub 1996/04/01. eng.

26. Mariette X. Sjogren's syndrome and virus. Ann Med Interne (Paris) 1995;146:243-246. [PubMed] PMID: 7653944. Epub 1995/01/01. eng.

27. Higashi K, Matsuki Y, Hidaka T, Aida S, Suzuki K, Nakamura H. Primary Sjogren's syndrome associated with hyaline-vascular type of Castleman's disease and autoimmune idiopathic thrombocytopenia. Scandinavian journal of rheumatology. 1997;26(6):482-4. PubMed PMID: 9433413. Epub 1997/01/01. eng.

28. Forteski, Denise de Fatima, Machado Netto, Fernanda Calil, Lomonte, Andrea Barranjard Vannucci, Anjos, Bruno César Cavalcanti dos, Zerbini, Maria Claudia Nogueira, \& Zerbini, Cristiano Augusto de Freitas. (2014). Multicentric Castleman disease not associated with HHV-8 and HIV virus- es. Revista Brasileira de Reumatologia, 54(4), 326329.

29. Beck JT, Hsu SM, Wijdenes J, Bataille R, Klein B, Vesole D, et al. Brief report: alleviation of systemic manifestations of Castleman's disease by monoclonal anti-interleukin-6 antibody. The New England journal of medicine. 1994 Mar 3;330(9):602-5. PubMed PMID: 8302342. Epub 1994/03/03. eng.

30. Ramos-Casals M, Brito-Zerón P. Emerging biological therapies in primary Sjögren's syndrome. Rheumatology. $2007 \quad$ September 1, 2007;46(9):1389-96.

31. Zulman J, Jaffe R, Talal N. Evidence that the malignant lymphoma of Sjogren's syndrome is a monoclonal B-cell neoplasm. The New England journal of medicine. 1978 Nov 30;299(22):1215-20. PubMed PMID: 309554. Epub 1978/11/30. eng.

32. Devauchelle-Pensec V, Mariette X, Jousse-Joulin S, Berthelot JM, Perdriger A, Puechal X, et al. Treatment of primary Sjogren syndrome with rituximab: a randomized trial. Annals of internal medicine. 2014 Feb 18;160(4):233-42. PubMed PMID: 24727841. Epub 2014/04/15. eng.

33. Grau JMC, Esquerdo GG, Ferrándiz CL, Garcia HB, Castellano MD, Moreno PF. Complete remission in a pancytopenic HIV negative, HHV-8 positive patient with multicentric Castleman's disease induced with anti-CD20. Clinical and Translational Oncology. 2006;8(7):540-1.

34. Ide M, Kawachi Y, Izumi Y, Kasagi K, Ogino T. Long- term remission in HIV- negative patients with multicentric Castleman's disease using rituximab. European journal of haematology. 2006;76(2):119-23.

35. Ibrahim K, Maghfoor I, Elghazaly A, Bakshi N, Mohamed SY, Aljurf M. Successful treatment of steroid-refractory autoimmune thrombocytopenia associated with Castleman disease with anti-CD-20 antibody (rituximab). Hematology/oncology and stem cell therapy. 2011;4(2):100-2. PubMed PMID: 21727772. Epub 2011/07/06. eng.

36. Flejsierowicz M, Ahmed MS, Kotov P, Cheng YC. Successful treatment of aggressive HIV-associated multicentric Castleman's disease: a case report. WMJ : official publication of the State Medical Society of Wisconsin. 2008 Jul;107(4):191-4. PubMed PMID: 18702436. Epub 2008/08/16. eng. 